\title{
Climate Change Impact on Aquifer System of Essaouira Basin during the Past 4 Decades (Morocco)
}

\author{
Salah Ouhamdouch'1, Mohammed Bahir ${ }^{2}$, Paula Carreira ${ }^{3}$, Najiba Chkir ${ }^{4}$, \\ Abdelmalek Goumih ${ }^{2}$, Hamid Chamchati ${ }^{1}$ \\ ${ }^{1} 3$ GEOLAB, Department of Geology, Faculty of Sciences Semlalia, Cadi Ayyad University, Marrakech, Morocco \\ ${ }^{2}$ Departement of Geology, E.N.S. of Marrakech, Cadi Ayyad University, Marrakech, Morocco \\ ${ }^{3}$ Química Analítica e Ambiental, IST/ITN, Universidade Técnica of Lisboa, Lisboa, Portugal \\ ${ }^{4}$ Ecole Nationale d'Ingénieurs de Sfax, Radio-Analyses et Environnement, Sfax, Tunisie \\ Email: salah.ouhamdouch@edu.uca.ma,bahir@uca.ma,carreira@itn.pt, Najiba_Chkir@yahoo.fr, \\ a.goumih@uca.ac.ma,chamchati.hamid@gmail.com
}

Received 21 May 2015; accepted 12 January 2016; published 15 January 2016

Copyright (C) 2016 by authors and Scientific Research Publishing Inc.

This work is licensed under the Creative Commons Attribution International License (CC BY).

http://creativecommons.org/licenses/by/4.0/

(c) (i) Open Access

\section{Abstract}

Since the 50s, many changes are observed in the climate of the globe, the warming of the atmosphere and the ocean, the decrease in the extent of snow and ice, and rising sea levels. In addition to the demographic pressure, the Maghreb countries are suffering from the drought, which accentuates the phenomenon of desertification and soil erosion, as well as their salinity, which leads to the salinization and depletion of water resources. In Morocco, the climate change leads to the erosion of the soil under the effect of desertification resulting in siltation of reservoirs and the increased salinization of soil and water resources. The Essaouira basin, which is the subject of this study, is located at the Western extremity of the High Atlas to the Southeast of the Essaouira city; between $31^{\circ} 20^{\prime}$ to $31^{\circ} 30^{\prime} \mathrm{N}$ and between $9^{\circ} 00^{\prime}$ to $9^{\circ} 46^{\prime} \mathrm{W}$. The basin is characterized by a semi-arid climate with average annual rainfall of around $300 \mathrm{~mm} \cdot y e a r^{-1}$ and an average temperature of $20^{\circ} \mathrm{C}$. Considering the importance of the aquifer in Essaouira in the supply of the region's groundwater, a study was conducted to assess quantitatively and qualitatively the impact of climate change on water resources in this area. The aquifers present in this region are one of cenomano-turonian upstream and plio-quaternary downstream, separated by the diaper of Tidzi. A piezometric map of the basin was made (1990-2009) and the hydrochemical method of the waters shows that they present a facies $\mathrm{Na}-\mathrm{Cl}$ with an electrical conductivity ranging from 700 to $7000 \mu \mathrm{s} / \mathrm{cm}$. The isotopic tracers like ${ }^{18} \mathrm{O},{ }^{2} \mathrm{H},{ }^{3} \mathrm{H}$ and ${ }^{14} \mathrm{C}$ were analyzed to determine the age of groundwater, and a right local meteoric close to the right meteoric world characterizing the precipitation of oceanic origin has been determined. The Essaouira basin turns out to be very vulnerable and sensitive to climate change because its recharge is entirely dependent on the rainwater. These results should be taken 
in consideration for the future water management in the region.

\title{
Keywords
}

\author{
Climate Change, Drought, Essaouira Basin, Hydrochemistry, Isotopy, Piezometry, Semi-Arid, Water \\ Resources
}

\section{Introduction}

Since the fifties, the earth's climate has undergone significant changes represented primarily by the warming due to greenhouse gas emissions, in close relationship with human activity. Among the consequences of these changes are noted for many countries: i) an increase of the temperature; ii) a decrease in precipitation, as well as the mass of ice sheets; iii) a rise in the level of the sea; and iiii) a scarcity of water resources. The countries of the Maghreb (Algeria, Morocco and Tunisia) have not been spared by the impact of these changes that negatively affect the most of their natural resources, including water resources. Locally, the basin of Essaouira, which is the object of this study is affected for several years, and this is reflected in the scarcity of water resources, increased salinity due to the invasion of sea water and increasing the salinity of the soil, degradation of the groundwater quality and the drying up of several sources.

\subsection{Climate Change on a Global Scale}

In its report of September 2013, the Intergovernmental panel on Climate change (IPCC) states that warming of the globe is, without a doubt, adding that human influence is the primary cause of this warming. Among the results of global warming, include:

+ The warming of the atmosphere: The last three decades are successively warmer at the earth's surface than all preceding decades since 1850 . The average global temperature shows a warming of the order of $0.85^{\circ} \mathrm{C}$ over the period 1880-2012 (Figure 1). Precipitation has increased since 1901 in the continental regions of the mid-latitude in the northern hemisphere, as well as in the East of South America, while a decrease was recorded in the Sahel, Mediterranean, southern Africa and parts of south Asia (Figure 2) [1].

+ The reduction of the surface area of the ice caps and glaciers: everywhere in the world, there is a reduction of the surface area of the ice caps, and ice cream. Over the past three decades, the range of annual average arctic sea ice has been decreasing at a rate of 3.5 to $4.1 \%$ per decade (Figure 3(a)) [1].

+ The increase in the level of the sea: since the early 1970s, the decrease in mass of glaciers and the thermal expansion of the oceans contribute to them only about $75 \%$ of the rise global mean sea level. Between 1901 and 2010, the increase in the average level of the sea has been estimated to be $19 \mathrm{~cm}$ (Figure 3(b)) [1].

\subsection{Climate Change in the Maghreb}

Like most countries of the world, the three countries of the Maghreb (Algeria, Morocco and Tunisia) have not been spared by climate change. For example, the north-west of Algeria has experienced a reduction of the order of $40 \%$ of annual rainfall from the first half of the 1970s. This reduction is accompanied by an increase in temperature. This change has affected the flow of the rivers of this region. According to the 4th IPCC report, the blades of water that have passed the annual averages for the period from 1976 to 2002 are from $28 \%$ to 36\% lower than those of the period 1949-1976, and this reduction is attributed primarily to climate change. According to the national institute of meteorology of Tunisia, the regime of rainfall in Tunisia during the 20th century as a whole has been marked by relative stability. This century has also been marked by the alternation of dry penriods (1940-1950) and wet periods (1950-1960). However, the temperature is rising $\left(1.1^{\circ} \mathrm{C}\right)$ since the sixties. In addition to this increase, Tunisia appears to be suffering from an amplification of the process of erosion that can dry out the soil and increasing consequently the salinity of the water tanks. In addition, the elevation of the sea level due to global warming will have serious impacts on the coastline such as the contamination of groundwater in the coastal waters of freshwater by marine waters [2] [3]. 


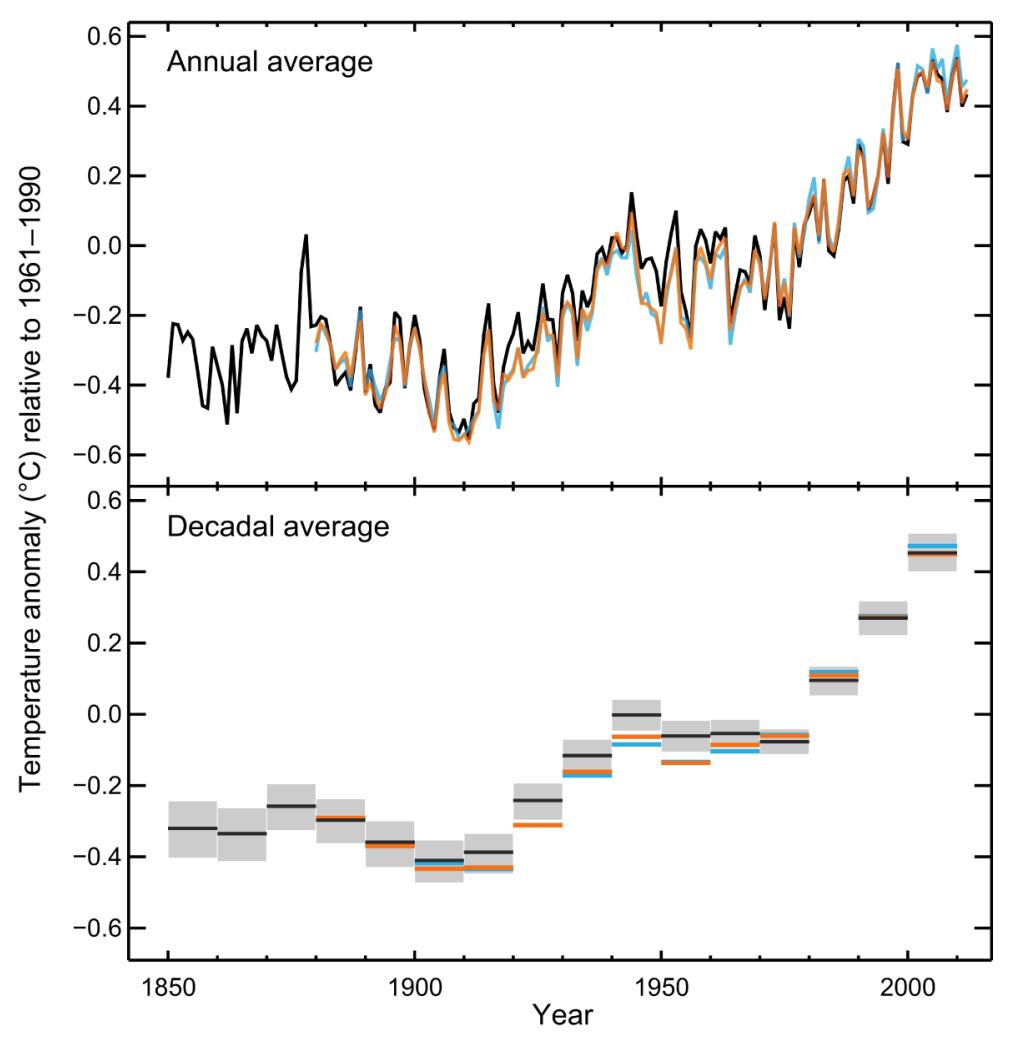

Figure 1. Observed Anomalies of average temperatures $\left({ }^{\circ} \mathrm{C}\right)$ on the surface of the globe [1].

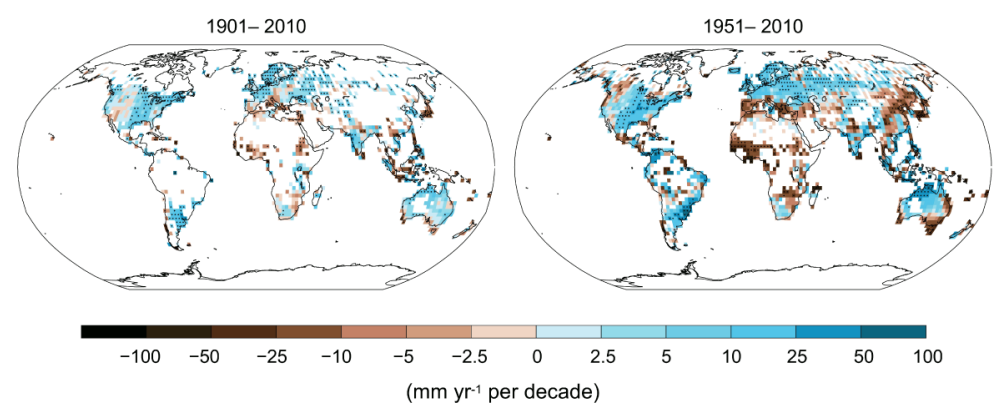

Figure 2. Maps of the observed changes in precipitation $\left(\mathrm{mm} \cdot \mathrm{yr}^{-1}\right)$ between 1901 and 2010, and between 1951 and 2010 [1].

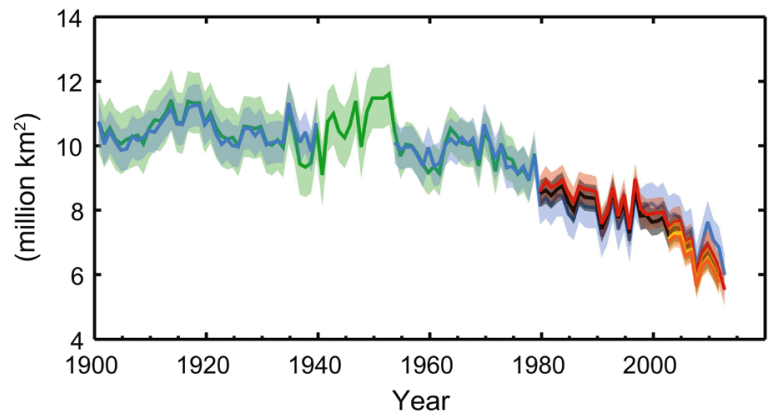

(a)

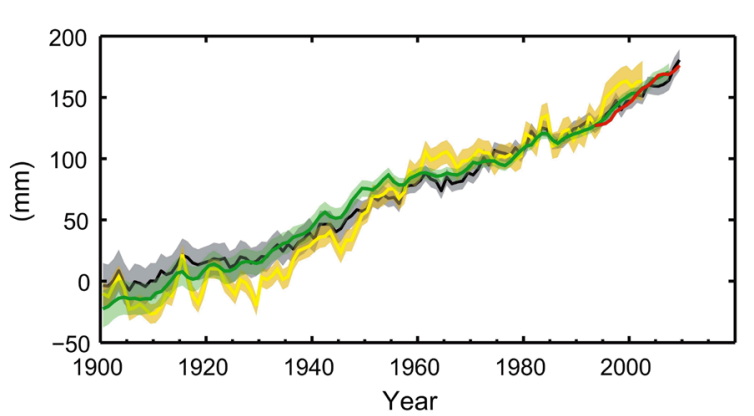

(b)

Figure 3. The extent of the arctic ice in the summer (million $\mathrm{km}^{2}$ ) (a); evolution of the mean sea level (mm) (b) [1]. 
In Morocco, water resources are limited, they are estimated at 20 billion $\mathrm{m}^{3}$, or an average of $700 \mathrm{~m}^{3} / \mathrm{capita} /$ year, which corresponds to a situation of water stress high enough. The number of years with rainfall deficit is everywhere more important than the number of surplus years (Figure 4). As found by various previous studies (including that of the minister of public works, 2007), we distinguish two dry periods: 1980-1985 and 19901995. However, the evolution of the temperature is steady and is increasing (Figure 5). Among the impacts resulting, include: 1) the soil erosion under the effect of desertification causing the silting up of the reservoirs of the dams; 2) the increase in the salinization of water resources and soil; 3) the lowering of the piezometric levels of groundwater on one side and the increase in the level of the sea on the other, which creates in the coastal areas, a reversal of current, the result of which is the invasion of sea water into the aquifers [4]-[6].

\section{Essaouira Basin}

\subsection{Geographic Location}

The Essaouira basin is located along the ocean in Morocco, specifically at the western end of the chain high atlas. This basin occupies an area of $1827 \mathrm{~km}^{2}$. It includes several aquifer systems whose structures and resources are often poorly known. The most important of these aquifer systems belong to two units synclines: the unit of Bouabout located in the eastern part of the basin and the unit of Essaouira synclinal who represents the western part of the basin. The Tidzi diaper separates these two units (Figure 6) [7].

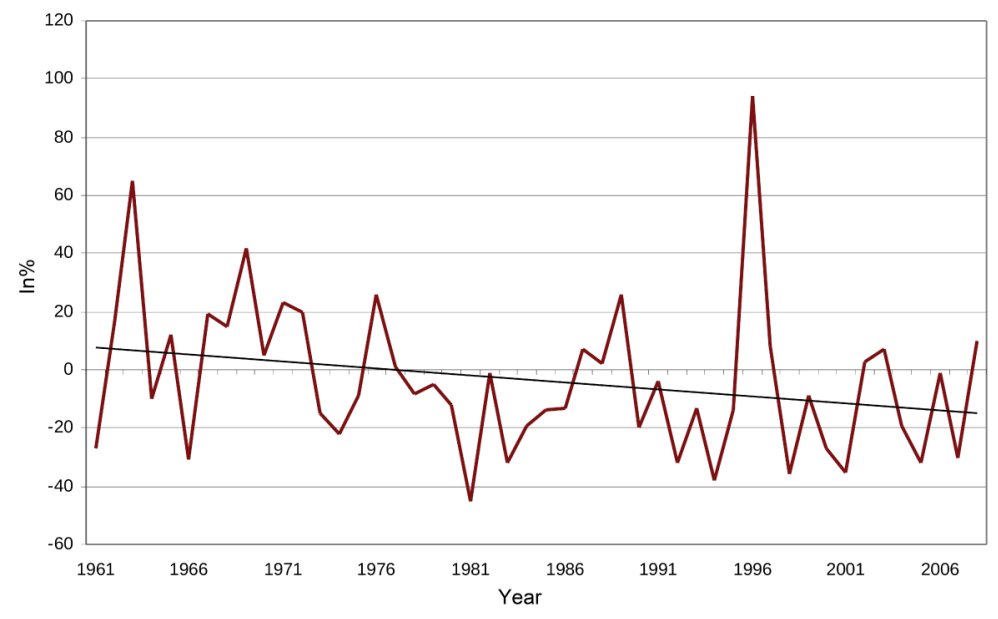

Figure 4. National averages (\%), defects of the cumulative rainfall totals annual, calculated on the 14 meteorological stations in Morocco. Period 19612008) [4].

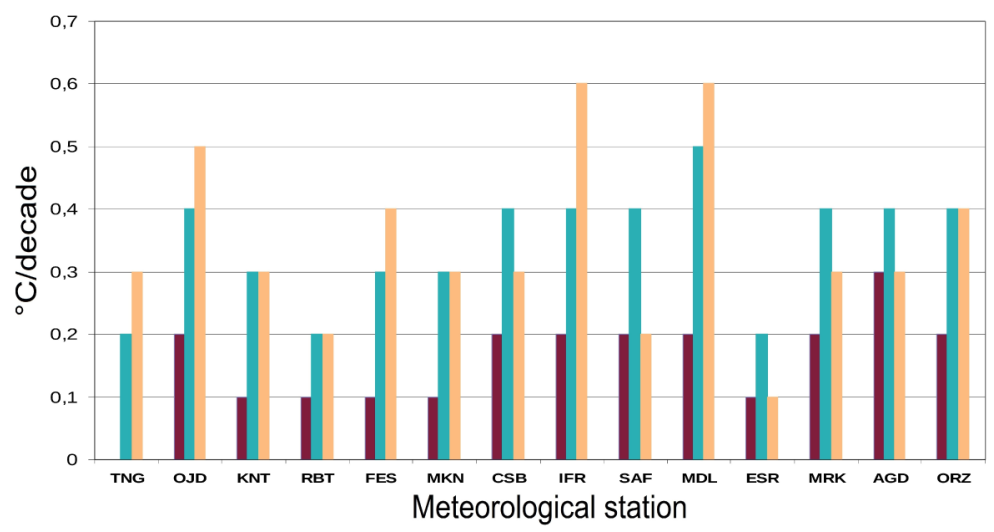

Figure 5. Trends in seasonal average temperatures $\left({ }^{\circ} \mathrm{C} /\right.$ decade) calculated over the period 1961-2008 at the level of the 14 meteorological stations. Winter: bar-purple, spring green bars, autumn: yellow bars [4]. 


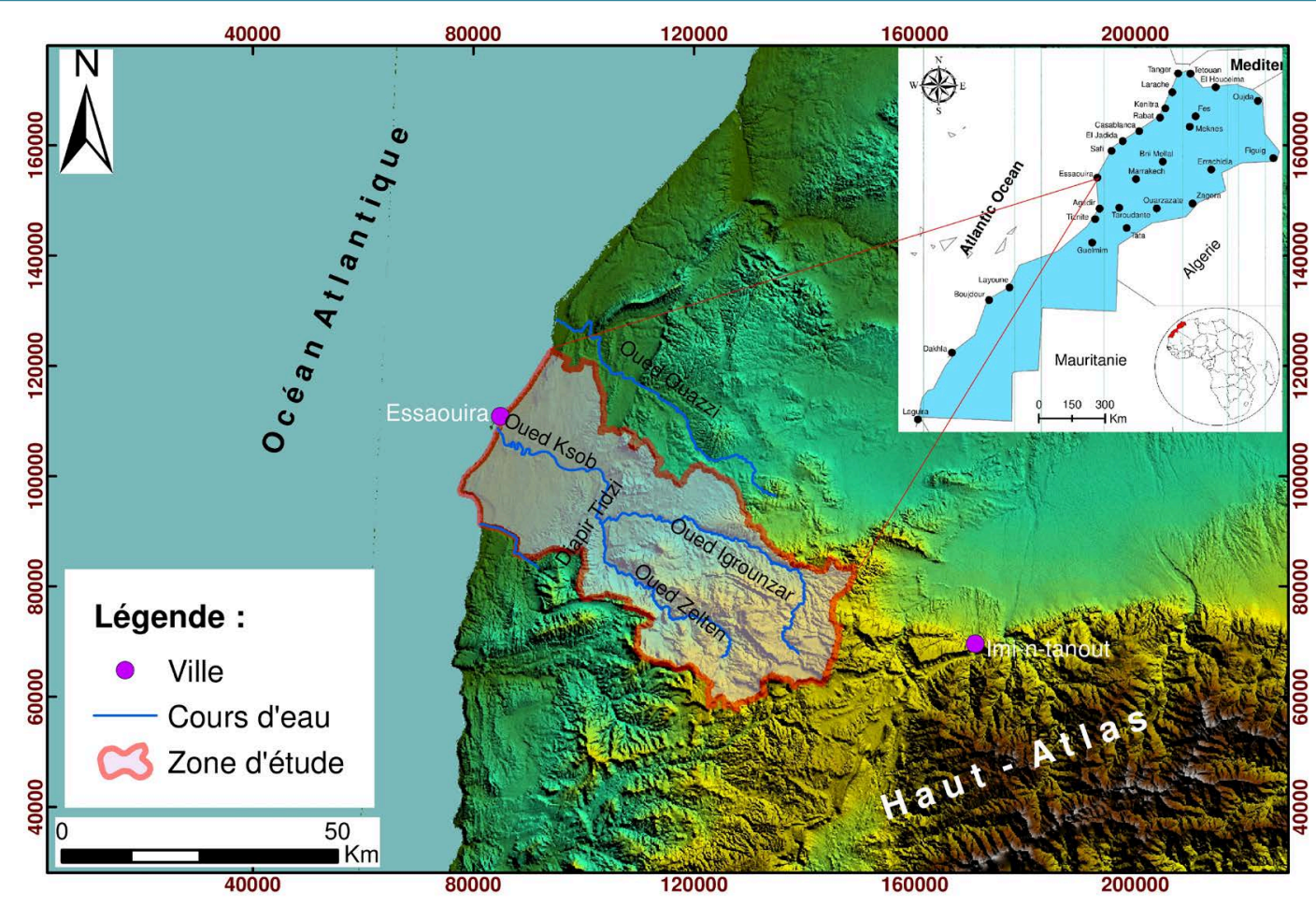

Figure 6. Location of the study area.

\subsection{Geological and Structural Context}

In the Essaouira basin, the Triassic formations and Jurassic have outcrops very small and localized to the core of anticlines (jbel Hadid NW, jbel Amstétene to the SW and Tidzi diaper), while the tertiary formations and quaternary are found in the basins synclines. The Triassic is composed of red clay salt, basalt diabase and pelites sandstone. The Jurassic is composed of an alternation of carbonate deposits (limestone and dolomite) and clayrich evaporates (gypsum and anhydrites). While the cretaceous to the quaternary period are presented in the log stratigraphic synthetic [8]. The Essaouira basin is a broad syncline area open on the Atlantic Ocean. It is affected by several folds and accidents that allow the individualization of the many bowls synclines: i) the bowl of Bouabout occupying the upstream part of the basin, crossed by the River Igrounzar; ii) the bowl of Kourimat and iii) the synclinal basin of Essaouira (part of the basin) separate from that of Bouabout by the Tidzi diaper which shows the outcrop of the subterranean Triassic. These depressions give rise to aquifer systems (Figure 7(a) and Figure 7(b)) [8].

-The profile EE' (Figure 8(a)), made in the East on the upstream side of the basin shows that the basin of Bouabout is fragmented by faults of the East-West direction. The Wadi Igrounzar representing the power source of the bowl is set on a large flaw. To the North, there is a failover of the blocks up to the bowl of Ouled Moumen [9].

-The profile DD' (Figure 8(b)) direction SSW-NNE shows that the Bouabout bowl is sandwiched between two blocks reassembled corresponding to the jbel Ihchich and the jbel Tamsrirt. To the North, there is the bowl of Kourimat that installs between two large faults [9].

-To the West of the upstream part of the basin (profile FF' (Figure 8(c)) and from the South to the North, one finds the Bouabout bowl limited between the Zelten ledge and the Igrounzar wadi. The latter corresponds to the boundary between the basin of Bouabout and Meskala. The heart of the two basins is occupied by training Senonian [9]. The synclinal basin of Meskala and Kourimat (CC' (Figure 8(d))) are separated by jbel Jehair, where outcrop of the formations from the mid-cretaceous (vraconian) [10].

-Downstream of the basin, the sections AA' (Figure 9(a)) and BB' (Figure 9(b)) show that this synclinal area is less rugged, with a low relief characterized by low hills. The core of the synclinal basin is occupied, respectively, from the top to the bottom by formations of plio-quaternary, Senonian, Turonian and Cenomanian. It is the headquarters of the two main reservoirs of underground water of the region: 1) the plio-quaternary is repre- 


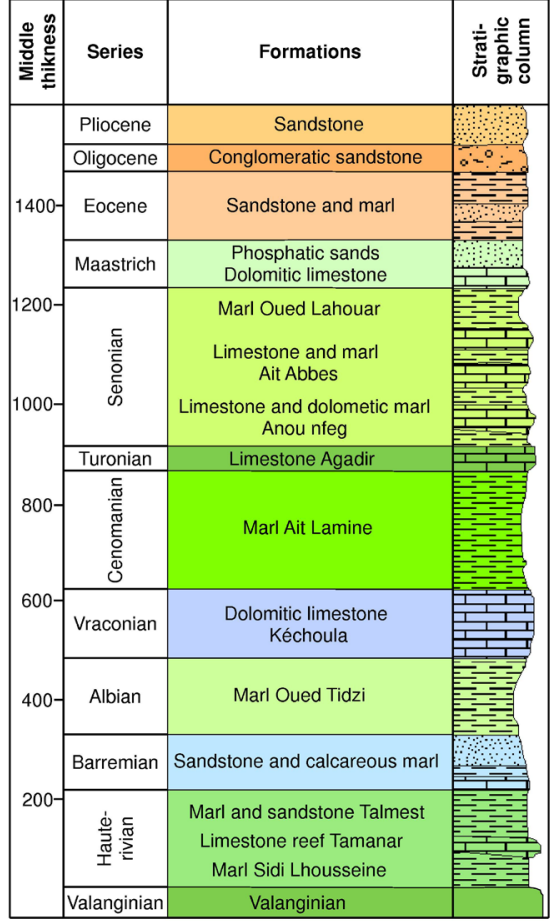

(a)

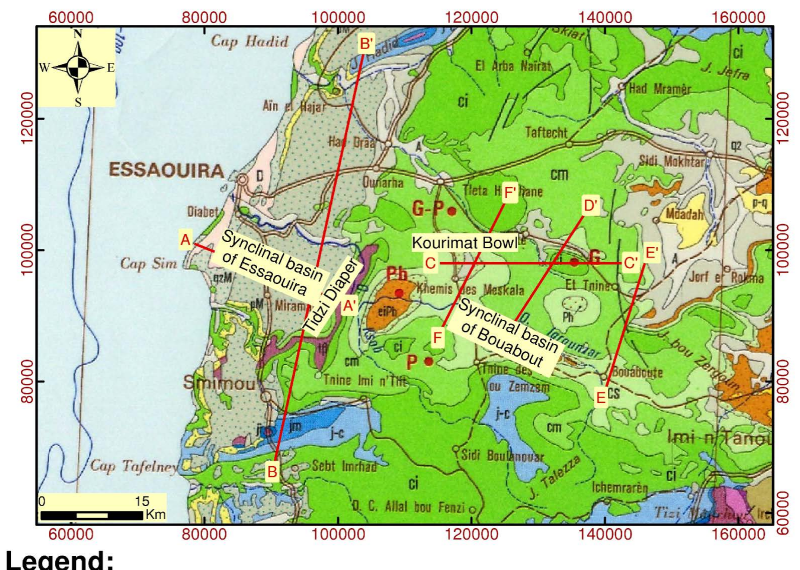

Legend:
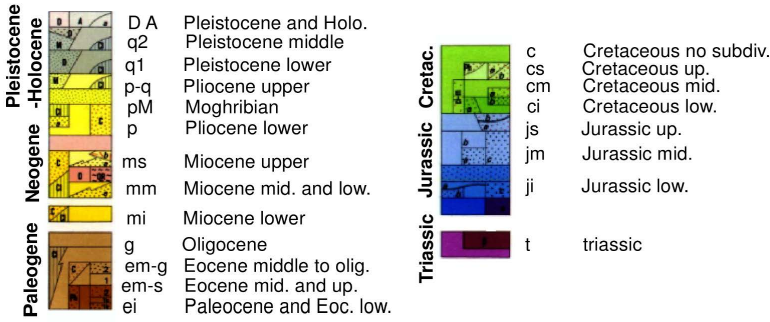

(b)

Figure 7. Log synthetic stratigraphic Cretaceous and Tertiary (a); geological map of the study area (b).

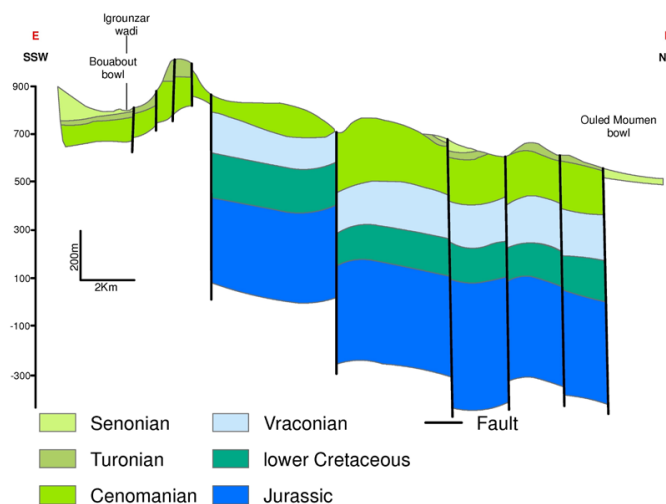

(a)

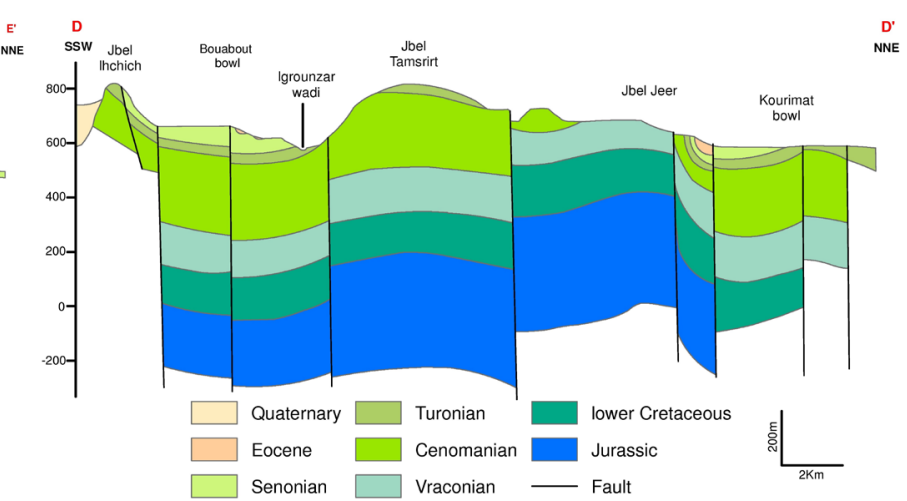

(b)

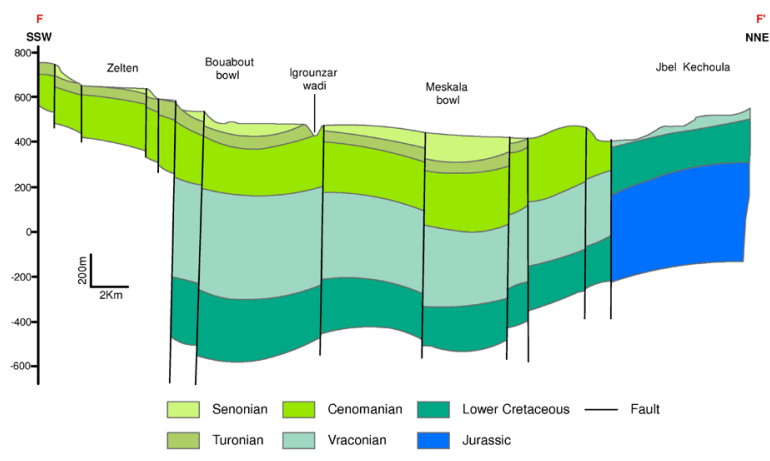

(c)

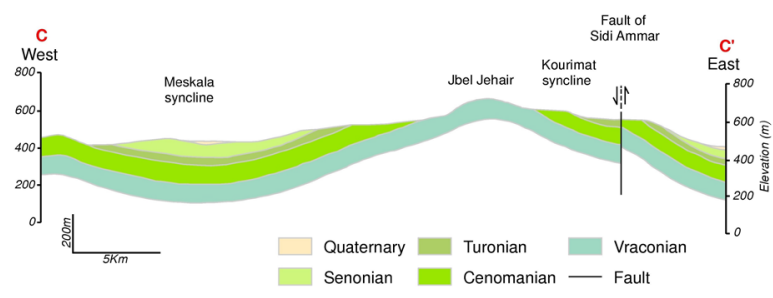

(d)

Figure 8. Geological profile EE’ (a); DD’ (b); FF’ (c) and CC’ (d). 


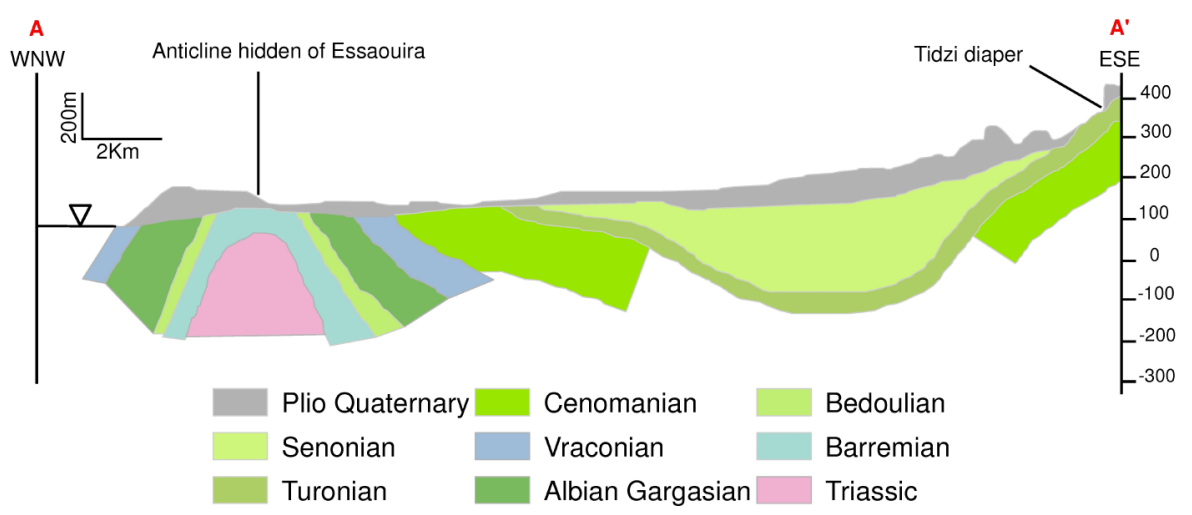

(a)

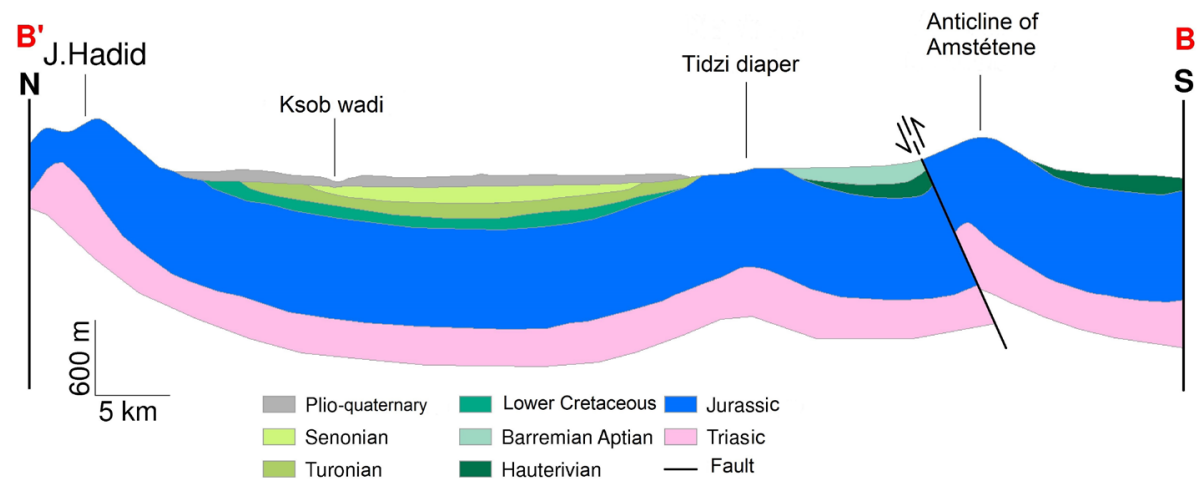

(b)

Figure 9. Geological profile AA’ (a); BB’ (b).

sented by the training matrix sandstone with a hydraulic conductivity primary porosity, it is a slick free material of which the wall is formed by marls of the Senonien; 2) the Turonian, which comes through the suite contains a tablecloth quickly captivates the heart of which is made up of dolomitic limestone's surrounded by formations of Cenomanian (wall of water). It is in direct contact with the plio-quaternary on the edges of the bowl. The Triassic is represented by the red clay salt and basalt diabase is appears at the level of the Tidzi diaper to the east of the basin, with an orientation NNE-SSW over a length of 20km. This basin is limited by the Ksob wadi in the North, Wadi Tidzi to the South, the Atlantic Ocean to the West and the Tidzi diaper to the East [7] [10].

\subsection{Climatic Context}

According to the aridity index of De Martonne (1) in which the equation cited below, the Essaouira basin is located in a semi-arid zone, characterized by the interference of the influence of the ocean (disruption of the west), continental and mountain. The aridity is marked in the basin, especially in the summer, it is relatively increased in going from the Atlantic to the continent. This growth aridity is the result of the removal of the influence of the ocean, where rainfall decreases and temperature variations are increasing.

$$
I=P /(T+10)
$$

With $P$ : average annual rainfall in $\mathrm{mm}$ and $T$ : annual average temperature in ${ }^{\circ} \mathrm{C}$. At the level of the station Igrounzar, the temperatures show a very significant seasonal variation. In winter, the minimum temperatures can reach up to $-11^{\circ} \mathrm{C}$, while the maximum is of the order of $40^{\circ} \mathrm{C}$ to $45^{\circ} \mathrm{C}$ [7]. According To the Ombrothermic diagram of Igrounzar station, and the hot season runs from March until October or even November, while the wet period lasts from November to march (Figure 10). The rainfall varies from year to year around an average of $306 \mathrm{~mm}$ (Figure 11). For the series of years stripped (1977-1978 to 2010-2011), we note the wet years, the height of which exceeds the average (1987-1989, 1995-1997, 2005-2006, 2008-2010). However, the rainfall show an irregular interannual striking. 


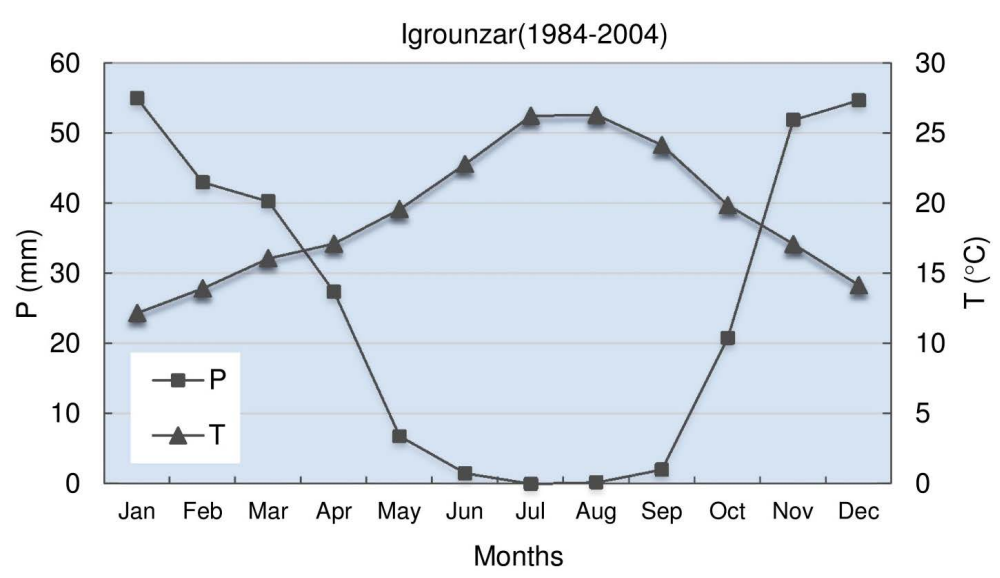

Figure 10. Ombrothermic diagram of Igrounzar station.

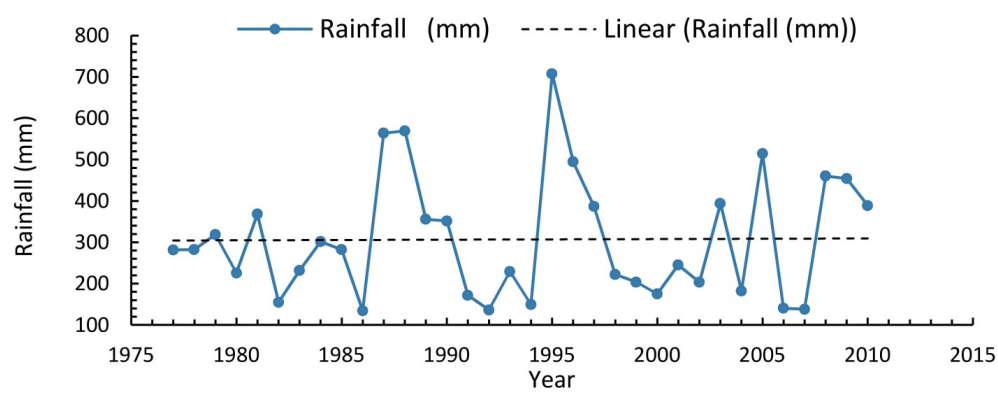

Figure 11. Evolution of the annual rains (mm) in Igrounzar station from 1977 to 2011.

\subsection{Piezometry}

To have an idea on the evolution of the piezometric level in the of Essaouira basin, we will handle in a first time the cenomano-turonian water of Bouabout (upstream part) and in the second time the water plio-quaternary water (downstream part) :

-Cenomanian-Turonian water (Bouabout): The companions of measuring the level piezometric carried out from 2006 to 2010 were used to establish the evolution curves of the water level of a water points number such as 1126/52 and 1726/52 (Figure 12). The graphical representation of the evolution of the groundwater level in the period 2006-2010 to these points shows a decrease of June 2006, the water level in October 2008. This decrease is explained by the drought affecting the region over the both 2007 and 2008 and by overexploitation of the aquifer for irrigation to offset the impact of drought. After October 2008, the water level begins to rise over a period of eight months, and then begins to decline.

-Water plio-quaternary: the campaigns of measurement of the piezometric level of the groundwater table, plio-quaternary during 1990, 1995, 2000, 2004 and 2009 resulted in the piezometric maps (Figure 13). They show a sense of global flow South-East to North-West, conditioned by the recovery of its substratum to the is a result of the uprising of the Tidzi diaper. A comparison of these maps piezometric reflects a decrease of piezometric levels in 1995 (the driest year of the century in Morocco). After that, a number of wet years, the occurrence of 1996-1997, 2002, 2003, 2004, 2006 and 2009 can restore and refit the piezometric level.

This variation of the piezometric level can be explained by the combined effect of climate change and overexploitation.

\subsection{Hydrochemistry}

The study of the chemical process of water for the purpose of identification of its chemical facies, its quality and potability, as well as its suitability for irrigation. The piper diagram shows that the groundwater plio-quaternary have the same family, characterized by the facies chlorides-sodium (Figure 14) [11]. Based on the electrical 

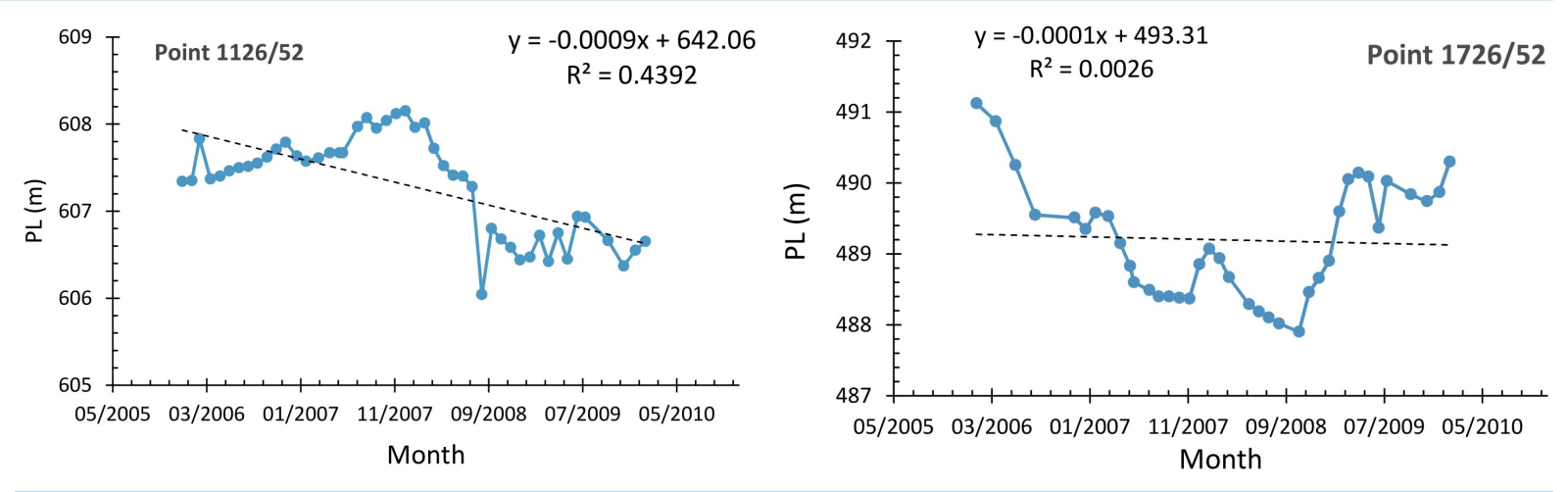

Figure 12. Evolution of the piezometric level (m) in the period 2006-2010 at the level of the water points 1126/52 and 1726/ 52 (2006 to 2010).
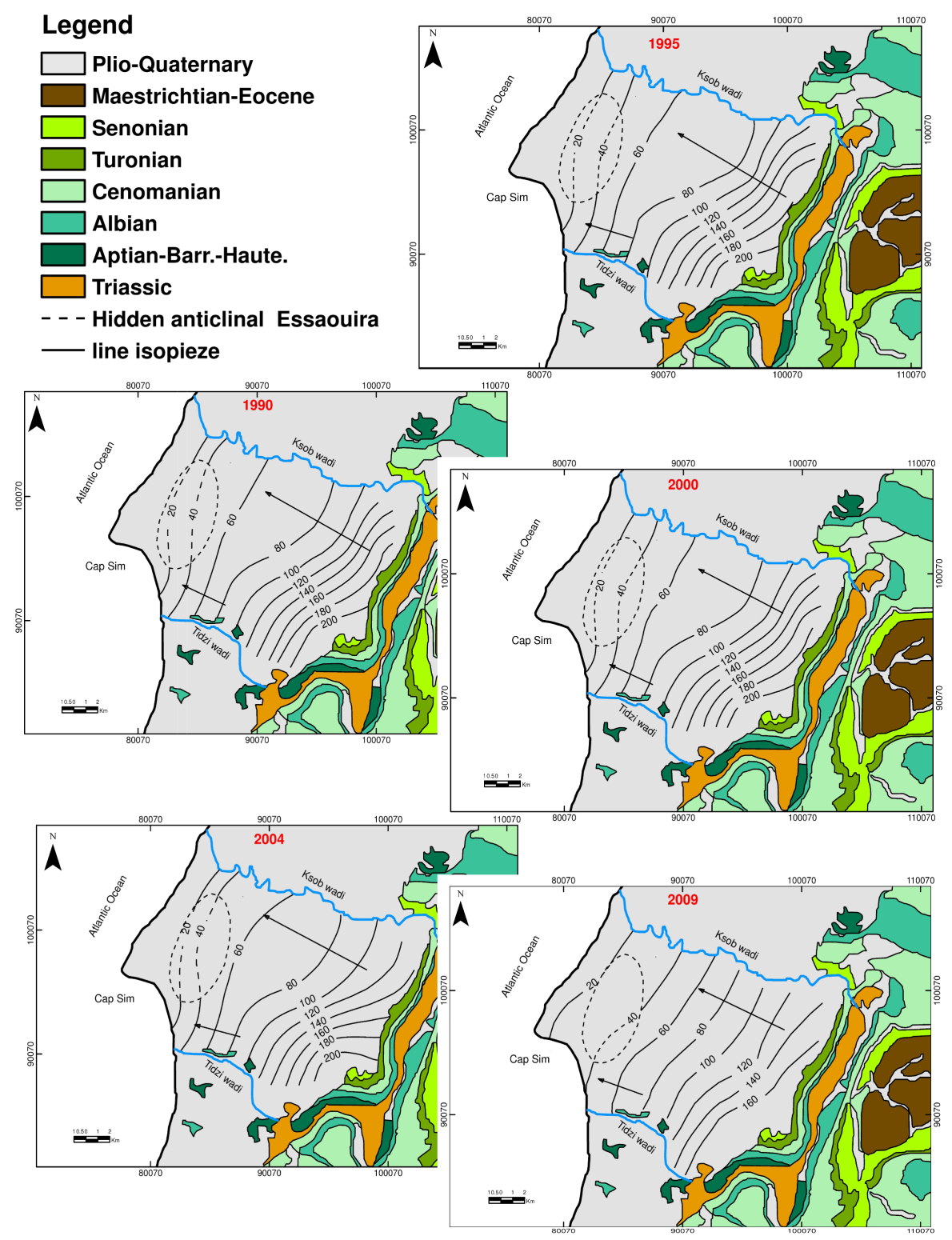

Figure 13. Piezometric maps of plio-quaternary groundwater of the synclinal area of Essaouira in 1990, 1995, 2000, 2004 and 2009. 


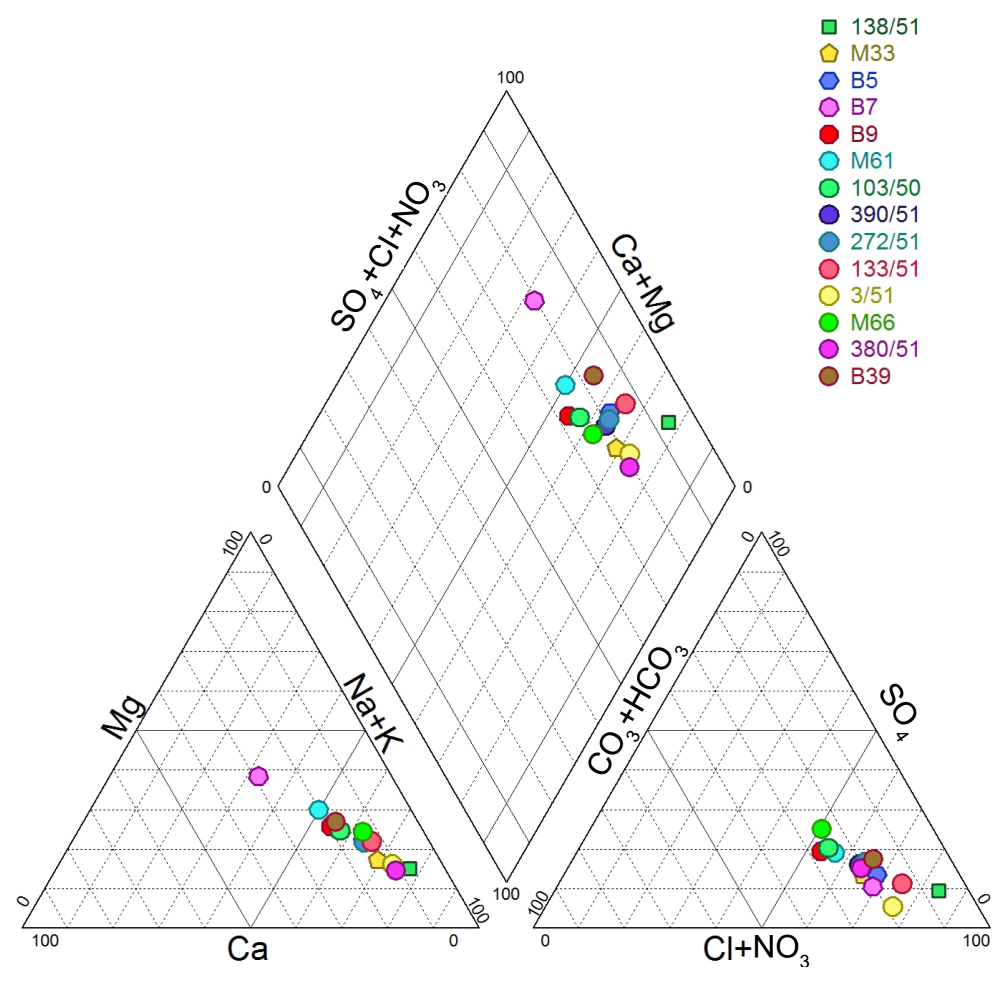

Figure 14. Chemical facies of groundwater plio-quaternary.

conductivity and chlorides of the waters of this aquifer, it can thus have an idea about the quality of the waters and its evolution. At the temporal scale, the quality of the water rises from the driest year that knows Morocco (1995) in 2009 through the year modestly dry and rainy. Spatially, it takes a growing sense in going from the north to the south of the aquifer (Figure 15). The temporal and spatial evolution of this quality is closely linked to rainfall.

\subsection{Isotopy}

In Essaouira basin, the hydrodynamic operation is strongly influenced by the structure (folds and faults), which determines the flow [7]. In the study area, the isotopes of the water molecule, the oxygen $18\left({ }^{18} \mathrm{O}\right)$, the deuterium $\left({ }^{2} \mathrm{H}\right)$, tritium $\left({ }^{3} \mathrm{H}\right)$ and carbon $14\left({ }^{14} \mathrm{C}\right)$, may provide elements of a response in the determination of areas and conditions of recharge of the aquifers and their relationships, and their age. The isotopic analyses were carried out within the institute of technology and nuclear power in Lisbon, the results of these analyses are present in Table 1. The isotopic content of the plio-quaternary water are between -3.72 and $-4.56 \delta \%$ vs smow. Those of Turonian groundwater are between -4.17 and $-4.55 \delta \%$ vs smow. The results of the analyses of deuterium can be set on a correlation diagram ${ }^{18} \mathrm{O}-{ }^{2} \mathrm{H}$ (Figure 16), the right local meteoric (LMWL) equation $\delta^{2} \mathrm{H}=7.72 \mathrm{x}^{18} \mathrm{O}+$ $10.53\left(\mathrm{R}^{2}=0.82\right)$ near the right of the meteoric waters world $(\mathrm{WMWL})$ slope 8 with excess deuterium neighbor of 10 [12]. It characterizes the precipitation of oceanic origin, the equation of this line was calculated without taking account of the three water points (390/51, 272/51 and Ksob wadi) identified as the evaporated because they are below the MWW. The point 272/51 marked by the evaporation of the plio-quaternary aquifer is located in the immediate vicinity of the wadi, which confirms the power of the water by the Ksob wadi already highlighted in the North-Eastern quarter of the area by the piezometry and mineralization lower of aquifer. The position of the point 390/51 capturing the Turonian water on the diagram ${ }^{18} \mathrm{O}-{ }^{2} \mathrm{H}$ indicates additional water evaporated. The other water points analyzed are aligned on the right of meteoric, which shows that the power of the water aquifer, including that of the Turonian aquifer is completed quickly without significant evaporation. The tritium is a radioactive element in the water cycle by precipitation. Its presence in groundwater with concentrations above 2 tritium units (UT) means a charging current [13]. By contrast, the water levels of less than 2UT are considered without active recharge [14]. For Morocco, the levels of precipitation is estimated to be about 

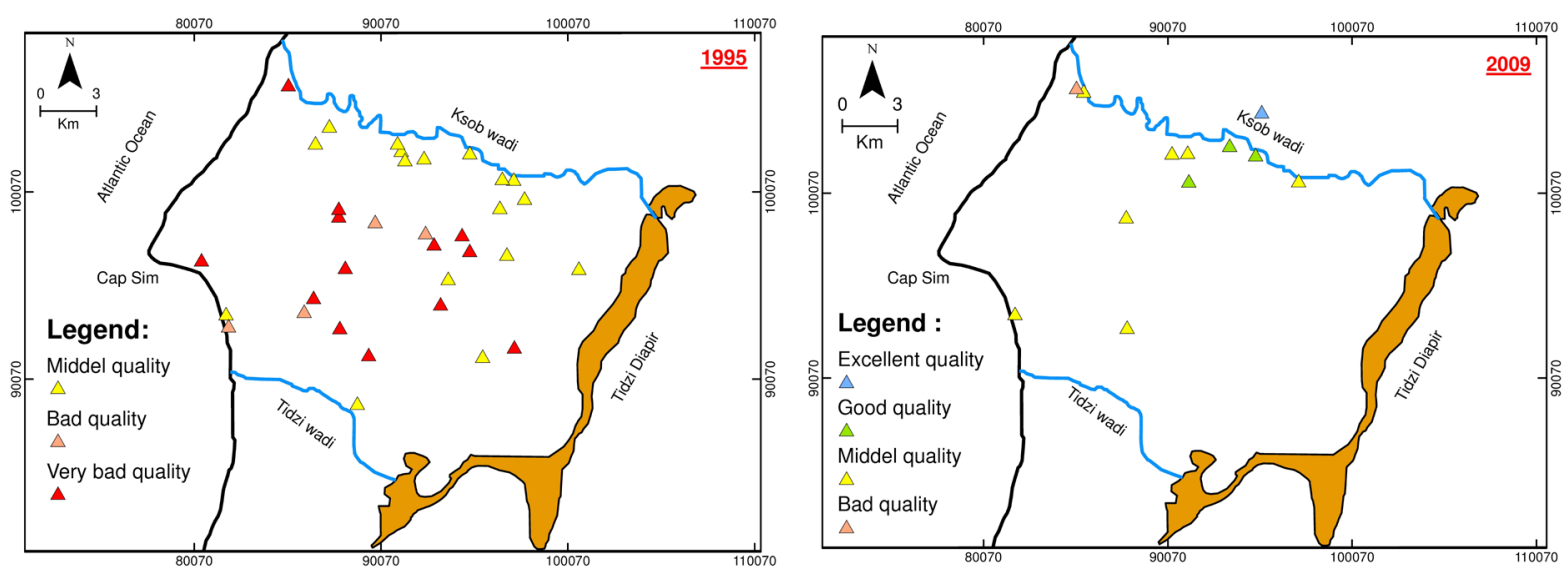

(a)
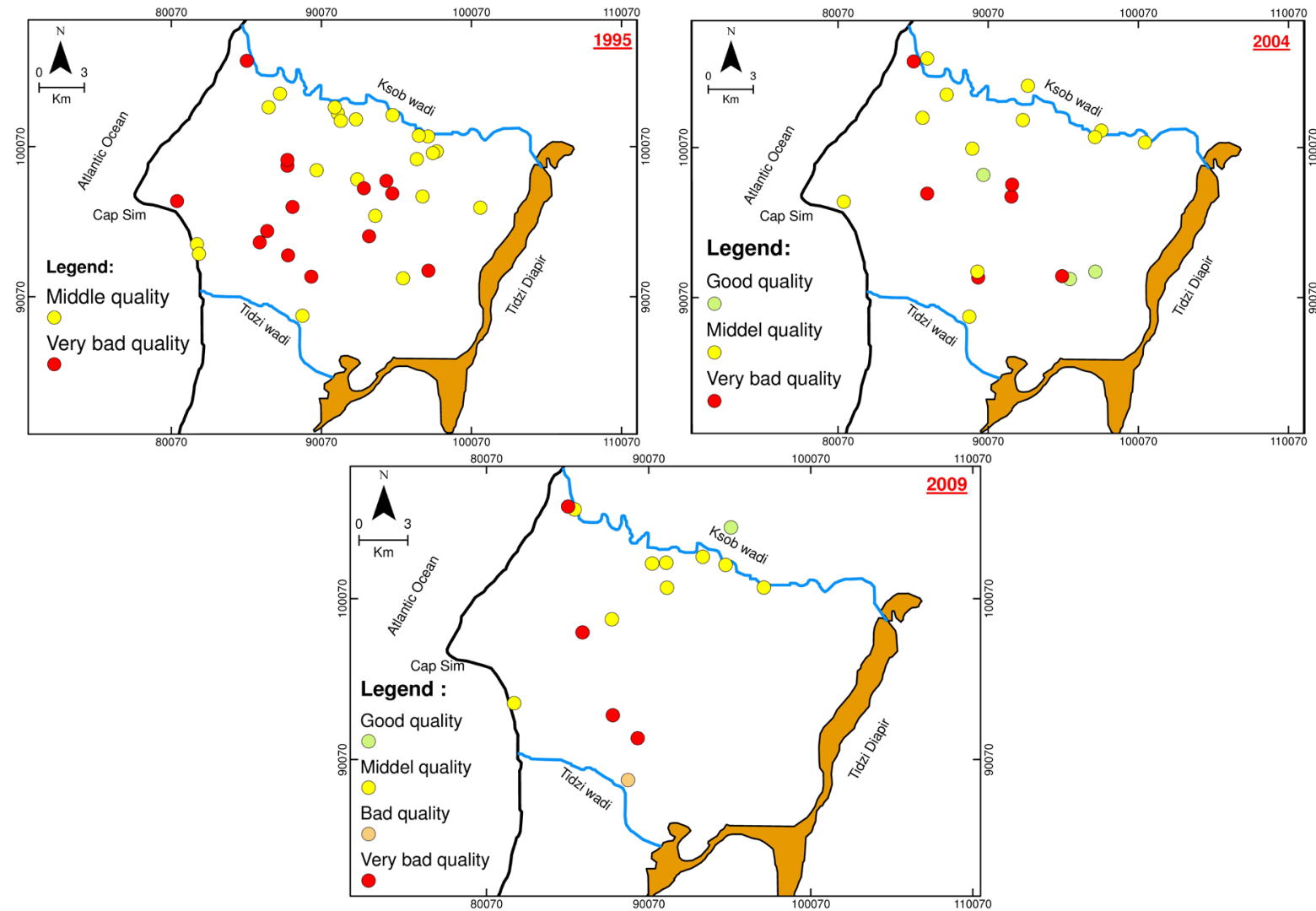

(b)

Figure 15. Temporal and spatial distribution of the groundwater quality in the aquifer plio-quaternary (from chlorides) (1995 and 2009) (a); groundwater quality (from electrical conductivity) (1995, 2004 and 2009) (b).

5UT [15]. Thirteen points of water capturing the various aquifers (except the Hauterivian) in the coastal area of Essaouira have been selected for the assay of tritium in their waters. The results are compiled in Table 2 and Table 3. The contents of tritium varied between a minimum value less than 0.8 UT and a maximum value of 4 UT. It follows from Table 2 that the recent waters in the coastal area of Essaouira contains levels of tritium between 2 and 4 UT. This is the case of water points 272/51, 65/51, 327/51 and 386/51, comforted by the elevated activities in ${ }^{14} \mathrm{C}$. Therefore, the points of which the content is less than $2 \mathrm{UT}$ are considered old waters, such as the case of points 21/51, M98, 216/51, 218/51, 361/51, 380/51, 290/51 and Aghbalou spring, some of which have been the subject of analysis in the ${ }^{14} \mathrm{C}$ to confirm or disprove the hypothesis. Table 2 brings together 


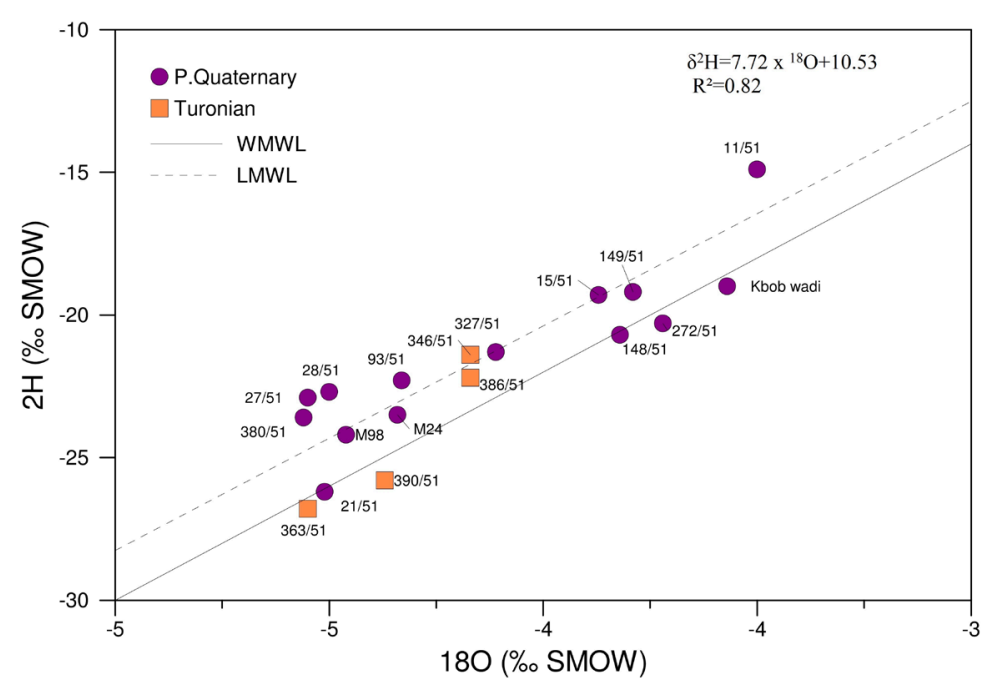

Figure 16. ${ }^{18} \mathrm{O}-{ }^{2} \mathrm{H}$ correlation in the groundwater in the area of Essaouira synclinal.

Table $1 .{ }^{18} \mathrm{O}$ and ${ }^{2} \mathrm{H}$ contents of the waters of the Essaouira synclinal basin.

\begin{tabular}{|c|c|c|c|c|c|}
\hline $\mathrm{N}^{\circ}$ Ire & $\begin{array}{c}\mathrm{X} \\
(\mathrm{m})\end{array}$ & $\mathrm{Y}$ & $\begin{array}{l}\mathrm{d}^{18} \mathrm{O} \\
(\%)\end{array}$ & $d^{2} H$ & Aquifer \\
\hline $149 / 51$ & 85,100 & 105,800 & -3.79 & -19.2 & Plio-Quat \\
\hline M98 & 89,000 & 100,000 & -4.56 & -24.2 & Plio-Quat \\
\hline $15 / 51$ & 86,000 & 97,000 & -3.87 & -19.3 & Plio-Quat \\
\hline $11 / 51$ & 80,450 & 96,450 & -3.5 & -14.9 & Plio-Quat \\
\hline $21 / 51$ & 89,400 & 91,400 & -4.51 & -26.2 & Plio-Quat \\
\hline $380 / 51$ & 89,350 & 91,800 & -4.56 & -23.6 & Plio-Quat \\
\hline $327 / 51$ & 88,800 & 88,800 & -4.11 & -21.3 & Plio-Quat \\
\hline $27 / 51$ & 95,500 & 91,300 & -4.55 & -22.9 & Plio-Quat \\
\hline M24 & 95000 & 91,500 & -4.34 & -23.5 & Plio-Quat \\
\hline $28 / 51$ & 97,200 & 91,800 & -4.5 & -22.7 & Plio-Quat \\
\hline $148 / 51$ & 85,700 & 102,050 & -3.82 & -20.7 & Plio-Quat \\
\hline Ksob wadi & 86,000 & 106,000 & -3.57 & -19 & Plio-Quat \\
\hline $93 / 51$ & 92,370 & 101,900 & -4.33 & -22.3 & Plio-Quat \\
\hline $272 / 51$ & 97,170 & 100,760 & -3.72 & -20.3 & Plio-Quat \\
\hline $386 / 51$ & 92,000 & 98,650 & -4.17 & -22.2 & Turonian \\
\hline $363 / 51$ & 89,750 & 88,200 & -4.56 & -26.8 & Turonian \\
\hline $390 / 51$ & 97,000 & 100,000 & -4.37 & -25.8 & Turonian \\
\hline $346 / 51$ & 97,250 & 100,700 & -4.17 & -21.4 & Turonian \\
\hline
\end{tabular}

the levels of tritium water providing drinking water to the Essaouira city. These waters are sampled in May 2004, and the analyses were performed in the institute of technology of Savacém in Lisbon. The levels of tritium contained in Table 2 vary from a minimum value less than 1.1 UT to a maximum value 4.2 UT. From this table we can derive that, recent waters in the coastal area of Essaouira contains levels of tritium above 2UT. This is notably the case of the water points 272/51 (borehole Idda-Ou Gourd) and 386/51 (borehole aerodrome) which 
Table 2. Physical parameters and analysis of radioactive isotopes of groundwater in the coastal area of Essaouira.

\begin{tabular}{|c|c|c|c|c|c|c|c|c|c|c|}
\hline $\mathrm{N}^{\circ} \mathrm{IRE}$ & Nature & Origin & $\begin{array}{l}\text { Altitude } \\
\text { (m) }\end{array}$ & Prof & $\begin{array}{c}\mathrm{T} \\
\left({ }^{\circ} \mathrm{C}\right)\end{array}$ & $\mathrm{PH}$ & $\begin{array}{c}\text { Alc } \\
\text { Méq/l }\end{array}$ & $\begin{array}{l}{ }^{3} \mathrm{H} \\
\text { UT }\end{array}$ & $\begin{array}{l}{ }^{14} \mathrm{C} \\
\text { pcm }\end{array}$ & $\begin{array}{l}{ }^{13} \mathrm{C} \\
{ }_{0}^{\circ}\end{array}$ \\
\hline $272 / 51$ & well & Plio-Q & 105.5 & 38.4 & 20.6 & 7.65 & 3.30 & 3.9 & & \\
\hline $21 / 51$ & well & Plio-Q & 135 & 29 & 21.7 & 7.13 & 2.80 & 2.0 & & \\
\hline $327 / 51$ & well & Plio-Q & 130 & & 22.2 & 7.23 & 4.03 & 3.2 & & \\
\hline $65 / 51$ & well & Turon & 15 & 20.3 & 22.5 & 7.48 & 4.64 & 2.8 & $88.9+/-0.5$ & -9.8 \\
\hline $390 / 51$ & borehole & Turon & 95 & 200 & 26.7 & 7.35 & 4.94 & $<2$ & $32.5+/-0.4$ & -9.4 \\
\hline $386 / 51$ & borehole & Turon & 105 & 100 & 23.2 & 7.56 & 4.26 & 4.2 & $84.8+/-0.6$ & -10.3 \\
\hline $380 / 51$ & borehole & Turon & 135 & 194 & 26.1 & 7.54 & 4.67 & $<2$ & $3.0+/-0.5$ & -9.0 \\
\hline M98 & borehole & Bar-Apt & 90 & 100 & 22.0 & 7.59 & 3.55 & 1.1 & $79.6+/-0.6$ & -9.3 \\
\hline A.Aghbalou & borehole & Bar-Apt & 80 & & 23.1 & 7.50 & 3.58 & 1.0 & $72.0+/-0.4$ & -10.0 \\
\hline $216 / 51$ & spring & Por-Ber & 160 & & 23.1 & 7.28 & 4.53 & 1.0 & & \\
\hline $218 / 51$ & spring & Por-Ber & 308 & & 22.5 & 7.29 & 4.24 & 1.0 & $68.5+/-0.6$ & -9.9 \\
\hline $361 / 51$ & borehole & Lias & 382 & 90 & 23.5 & 7.22 & 4.45 & 2.0 & & \\
\hline $203 / 51$ & borehole & Callow & 14 & 50 & 22.7 & 7.11 & 4.26 & 3.8 & & \\
\hline
\end{tabular}

Table 3. Campaign of May 2004 for the dating of the main points ${ }^{3} \mathrm{H}$ supplying drinking water to the Essaouira city.

\begin{tabular}{ccccccccccc}
\hline $\mathrm{N}^{\circ} \mathrm{IRE}$ & $\begin{array}{c}\mathrm{X} \\
(\mathrm{Km})\end{array}$ & $\mathrm{Y}$ & $\begin{array}{c}\mathrm{Z} \\
(\mathrm{m})\end{array}$ & $\mathrm{N} . \mathrm{P}$ & $\mathrm{H}$ & $\begin{array}{c}\mathrm{CE} \\
\mu \mathrm{s} / \mathrm{cm}\end{array}$ & $\begin{array}{c}\mathrm{T} \\
\left({ }^{\circ} \mathrm{C}\right)\end{array}$ & $\mathrm{pH}$ & Aquifer & ${ }^{3} \mathrm{H}$ \\
\hline $261 / 51$ & 96.42 & 99.25 & 124 & 46 & 88 & 1900 & 23.2 & 7.40 & Plio-Q. & $1.4+/-0.6$ \\
$390 / 51$ & 97 & 100 & 105.5 & 26.2 & 79.3 & 1890 & 25.9 & 7.15 & Turon. & $2.0+/-0.6$ \\
$386 / 51$ & 92 & 98.65 & 105 & 30.7 & 74.30 & 2260 & 18.5 & 7.70 & Turon. & $2.5+/-0.7$ \\
$272 / 51$ & 97.17 & 100.76 & 105.5 & 36 & 69.5 & 1917 & 20.9 & 7.42 & & $4.5+/-0.7$ \\
$6 / 51$ & 86.1 & 105.4 & 25 & 25 & & 2780 & 23.4 & 7.01 & Turon. & $1.4+/-0.7$ \\
$346 / 51$ & 97.25 & 100.7 & 105 & 26 & 79 & 1830 & 26.5 & 7.24 & Turon. & $1.5+/-0.6$ \\
$363 / 51$ & 89.75 & 88.2 & 150 & 60 & 90 & 2600 & 24.5 & 7.14 & Turon. & $1.2+/-0.8$ \\
$380 / 51$ & 89.35 & 91.8 & 135 & 55 & 80 & 2180 & 21.10 & 8.26 & Plio-Q. & $0.9+/-0.7$ \\
M98 & 89 & 100 & 125 & 80 & 45 & 2460 & 21.5 & 7.47 & Plio-Q. & $1.1+/-0.6$ \\
$149 / 51$ & 85.1 & 105.8 & 40 & 36.2 & 3.8 & 2800 & 23.3 & 7.83 & Plio-Q. & $0.2+/-0.8$ \\
\hline
\end{tabular}

Table 4. Calculate the initial ${ }^{14} \mathrm{C}$ activity and age of groundwater in the coastal area of Essaouira.

\begin{tabular}{|c|c|c|c|c|c|c|c|c|c|c|}
\hline \multirow[b]{2}{*}{$\begin{array}{l}\text { Points } \\
\text { d'eau }\end{array}$} & \multicolumn{2}{|c|}{ Tamers } & \multicolumn{2}{|c|}{ Pearson } & \multicolumn{2}{|c|}{ Fontes-Garnier } & \multicolumn{2}{|c|}{ AIEA } & \multicolumn{2}{|c|}{ Evans } \\
\hline & $\begin{array}{l}\text { Age } \\
\text { (ans) }\end{array}$ & $\begin{array}{c}\mathrm{A} 0 \\
(\mathrm{pcm})\end{array}$ & $\begin{array}{l}\text { Age } \\
\text { (ans) }\end{array}$ & $\begin{array}{c}\mathrm{A} 0 \\
(\mathrm{pcm})\end{array}$ & $\begin{array}{l}\text { Age } \\
\text { (ans) }\end{array}$ & $\begin{array}{c}\mathrm{A} 0 \\
(\mathrm{pcm})\end{array}$ & $\begin{array}{l}\text { Age } \\
\text { (ans) }\end{array}$ & $\begin{array}{c}\mathrm{A} 0 \\
(\mathrm{pcm})\end{array}$ & $\begin{array}{l}\text { Age } \\
\text { (ans) }\end{array}$ & $\begin{array}{c}\mathrm{A} 0 \\
(\mathrm{pcm})\end{array}$ \\
\hline $65 / 51$ & actuel & 53.6 & actuel & 46.7 & actuel & 46.4 & actuel & 76.5 & actuel & 44.6 \\
\hline $390 / 51$ & 4267 & 54.5 & 2646 & 44.8 & 2558 & 44.3 & 6445 & 70.9 & 2128 & 42.0 \\
\hline $386 / 51$ & actuel & 53.0 & actuel & 49.0 & actuel & 48.9 & actuel & 79.9 & actuel & 47.0 \\
\hline $380 / 51$ & 23739 & 53.0 & 21984 & 42.9 & 21891 & 42.4 & 25829 & 68.2 & 21443 & 40.1 \\
\hline M98 & actuel & 52.8 & actuel & 44.3 & actuel & 44.0 & actuel & 72.9 & actuel & 42.2 \\
\hline A. Aghbalou & actuel & 53.4 & actuel & 47.6 & actuel & 47.4 & 624 & 77.6 & actuel & 45.5 \\
\hline $218 / 51$ & actuel & 55.3 & actuel & 47.1 & actuel & 46.8 & 994 & 77.3 & actuel & 45.1 \\
\hline
\end{tabular}


feed, respectively, in drinking water for the Essaouira city and Idda-Ou-Gourd, comforted in it already by the results of 1996. Therefore, the campaign May 2004 confirms charging recent of these points. In contrast, the water levels are lower than or equal to 2UT are considered old waters, this is the case of points 261/51, 390/51, 346/51, 61/51 and M98. The Turonian aquifer water, which provides drinking water for the Essaouira city, for more than 50\%, especially the boreholes of more than $300 \mathrm{~m}$ deep 346/51 and 390/51 and the spring 6/51 show levels of tritium less than or equal to 2UT [10]. The new deal of the 2004 campaign for the analyses of tritium is charging low or no existent for the plio-quaternary boreholes, particularly the drilling 261/51 that sustains for more than 6l/s the Essaouira city. This is supported by its remote position Ksob wadi which food during floods the water points adjacent. The carbon 14 is the radioelement the most used to date ancient waters with very low tritium content. Seven points of water in the coastal area of Essaouira have been chosen for the determination of ${ }^{14} \mathrm{C}$ in their waters (Table 2). To estimate the initial activities of ${ }^{14} \mathrm{C}$ in these ground waters, several models were tested (Table 4). These different models can take into account the chemical dilution of the ${ }^{14} \mathrm{C}$ of the isotopic mixtures, or mixtures of isotopes with isotopic exchange. The analysis of Table 2 and Table 4 identifies that: the two water points $65 / 51$ and 386/51 have significant assays in ${ }^{3} \mathrm{H}$ and percentages in ${ }^{14} \mathrm{C}$ higher than $85 \%$, which makes them, as well as current. The well 65/51 located near the Ksob wadi, collects water from the Turonian aquifer provides the Essaouira city in drinking water. This well present a content ${ }^{18} \mathrm{O}$ of -4.53 intermediate value between the isotopic content of -4 of water plio-quaternary and -5 of Turonian waters, indicating a drainance pumping of the aquifer plio-quaternary. The borehole 386/51 capturing the waters of the Turonian aquifer supplies drinking water to the airfield of the Essaouira city. The borehole M98, which has no detectable ${ }^{3} \mathrm{H}$ and has a ${ }^{14} \mathrm{C}$ content of $80 \%$, shows a power prior to the nuclear tests of the years 1952 to 1963 , and its radiocarbon age may not exceed a few hundreds of years regardless of the interpretation model used. The borehole 390/51 capturing the waters of the Turonian aquifer, which supplies the Essaouira city with a debit of $60 \mathrm{l} / \mathrm{s}$, which is $50 \%$ of the water needs. This drill has a radiocarbon age of the order of 6500 years after the model of the IAEA, a little lower, but still several thousand years according to the other models. This reflects that it is in the presence of a water-very old and is in the process of exhausting a strategic resource, which could be used in extreme cases. The drilling 380/51 capturing the waters of the Turonian aquifer is located in the same position as the drilling 390/51. This drill has a radiocarbon age greater than 20,000 years regardless of the model used, indicating also the low rate of renewal of the Turonian water. The current activity in the ${ }^{14} \mathrm{C}$ of the Aghbalou spring that deaf aquifer Barremian-Aptian, providing drinking water and drank herd of a population of 10,000 peoples, with a flow rate of $30 \mathrm{l} / \mathrm{s}$, has a tritium content of less than 2UT. His power is, therefore, prior to the nuclear tests and its radiocarbon age is of a few hundreds of years regardless of the model.

\section{Conclusion}

Warming of the climate system is unequivocal, it is closely related to human activity. Among its consequences: The warming of the atmosphere and ocean, extended the reduction of the ice caps that in turn leads to rising sea level. In addition to demographic pressures, cultural practices and pastoral and climate change makes the Maghreb countries (Algeria, Morocco and Tunisia) in alarming water situation shown by: 1) drought which accentuates the desertification phenomenon; 2) enhancement of soil salinity and lowering groundwater levels groundwater. The complementarity of approaches hydroclimatic, hydrodynamic, hydrochemical and isotopic can lead to the diagnosis of aquifers vulnerable state of the Essaouira Basin to climate change. However, the development of a rational strategy for groundwater exploitation takes place in order to mitigate the effect of climate change. Such the case for treated wastewater for irrigation and seawater for drinking water supply.

\section{Acknowledgements}

This research was carried out within the Laboratory 3GEOLAB science faculty Semlalia of Marrakech; Cadi Ayyad University, in collaboration with the ENS of Marrakech and the Institute of Technology Nuclear Lisbon, Portugal. Our acknowledgments will go to the agents of the agency of the Basin Hydraulic Tensift that contributed to the realization of this work. We also thank the research group of Professor Paulà Carreira at the institute of technological and nuclear Lisbon, who has done isotope analyses.

\section{References}

[1] GIEC (2013) Changements climatiques 2013 les éléments scientifiques-résumé à l’intention des décideurs. 1-34. www.climatechange2013.org 
[2] Driouech, F., Ben Rached, S. and El Hairech, T. (2013) Climate Change and Food Security in West Asia and North Africa. Springer Science + Business Media, Dordrecht, 161-171.

[3] Nouaceur, Z., et al. (2013) Changements climatiques au maghreb: Vers des conditions plus humides et plus chaudes sur le littoral algérien. Physio-Geo, 7, 307-323. http://dx.doi.org/10.4000/physio-geo.3686

[4] Driouech, F. (2010) Distribution des précipitations hivernales sur le Maroc dans le cadre d'un changement cli matique: Descente d'échelle et incertitudes. Thèse de doctorat de l'université de Toulouse, 163.

[5] Sebbar, A., et al. (2011) Etude de la variabilité du régime pluviométrique au Maroc septentrional (1935-2004). Sécheresse, 22, 139-148.

[6] Sinan, M., et al. (2009) Changements climatiques: Causes et conséquences sur le climat et les ressources en eau. Revue HTE N ${ }^{\circ}$ 142. Mars-Juin 2009, 21-30.

[7] Bahir, M. (2007) Isotopes et ressources en eaux en zones-arides et semi-arides: Exemple du bassin d'Essaouira, 175.

[8] Duffaud, F., Brun, L. and Planchot, B. (1966) Bassin du Sud-Ouest Marocain (SW Morocco Basin). In: Reyre, Ed., Bassin Sédimentaire du Littoral Africain, Vol. 9, 18.

[9] Lahoucine, H. (1994) Caractérisation de la structure et du fonctionnement de l'aquifère crétacé du bassin d'Essaouira. Docteur d'état es-sciences. Faculté des sciences et techniques, Cadi Ayyad.

[10] Jalal, M., Bahir, M. and Mennani, A. (2001) Pollution nitratée des eaux souterraines du bassin synclinal d’Essaouira (Maroc) (Nitrate in groundwater of the Essaouira Synclinal Basin, Morocco). Journal of Environmental Hydrology, 9, $1-10$.

[11] Bahir, M. and Chamchati, H. (2011) Caractérisation du système aquifère plio-quaternaire et turonien (Bassin d'Essaouira, Maroc). Geohydro, 1-6.

[12] Craig, H. (1961) Standard for Reporting Concentration of Deuterium and Oxygen 18 in Natural Waters. Science, 133, 1833-1834.

[13] Olive, P., Hubert, P. and Ravailleau, S. (1996) Estimation pratique de l'age des eaux souterraines en Europe par le tritium. Revue des sciences de l'eau/Journal of Water Science, 9, 523-533.

[14] Olive, P. (1999) Datation des eaux souterraines à long de temps de résidences par le radioacarbone. Mode d'emploi. hydrogéologie, $\mathrm{N}^{\circ} 1$.

[15] Louvat, D. and Bichara, S. (1990) Etude de plusieurs systemes aquifères du Maroc à l'aide des isotopes du M lieu. Rapport AIEA. Vienne. 30 p. 